\title{
Parametric Study on Window-Wall Ratio (WWR) for Day lighting Optimization in Multi-Story Residential Buildings: Case Study of an Apartment Complex in Mansoura City, Egypt
}

\author{
Aliaa A. Yassin ${ }^{1}$, Sherif A. Sheta ${ }^{2}$, Mona A. ELWazeer ${ }^{3}$ \\ Demonstrator, University of Mansoura, Dept. of Architectural Engineering, Faculty of Engineering, Dakahlia, Egypt ${ }^{1}$ \\ Assoc. Prof. University of Mansoura, Dept. of Architectural Engineering, Faculty of Engineering, Dakahlia, Egypt ${ }^{2}$ \\ Lecturer, University of Mansoura, Dept. of Architectural Engineering, Faculty of Engineering, Dakahlia, Egypt ${ }^{3}$
}

\begin{abstract}
Energy consumption has become a major concern of global discussions among engineers, architects, scientists and planners. There are many ways to tackle this issue by saving energy in many sectors. Lighting is one way used to saving energy as it is used in many applications and it is one of the areas to be addressed for improving the energy efficiency in order to reducing the energy consumption. Natural daylight inside space considered one of the most important affairs because of its importance in caving energy consumption and its ability to provide a comfort environment inside space for occupants. Daylight in the residential building is a Major shareholder to save the energy consumption because it is the most significant natural resources available to engineers and architects to improve the visual comfort quality of interior spaces. A considerable reduction in artificial lighting and energy consumption can be achieved by maximize the use of natural day lighting. So, strategies are needed for more daylight optimization in the residential building spaces where electricity demand is very high. There are some design factors which architects should consider, namely: fenestration, climate conditions, orientations, and shading devices. As it is known that windows are the greatest resource to allow daylight into buildings, and proper window design also improves the thermal comfort and produces a significant energy savings in electric lighting. This paper aims to study the effect of Window-Wall Ratio (WWR) in Multi-Story Residential Building as one of the passive design strategies to optimize daylighting in residential buildings in Mansoura City, according to the framework of the Egyptian construction law which puts a lot of parameters which effect the daylighting of buildings, including buildings height and its relationship to the street width in addition to linking windows area of the residential spaces with the residential spaces area , thus to find a relationship between the percentage of housing openings and the elevation angle of the opposite buildings depending on the requirements of the global natural lighting and compare that Egyptian law. Rhino as a recommendation for building designers to use it at the early stages of design. This study was carried out by simulations on rhino software by using diva plugin in rhino program for calculation of daylighting during living hours. An investigation on the optimum amount of window size has been done by studying a living room model with $5.4 \mathrm{~m} \times 3.6$ $\mathrm{m} \times 2.7 \mathrm{~m}$ dimension expanding in vertical and horizontal level.
\end{abstract}

Keywords: Daylight, Window Wall Ratio (WWR), Residential Building, Diva for rhino simulation software, Daylight Autonomy.

\section{INTRODUCTION}

This research is focused on determining the appropriate design of the windows to provide optimum levels of daylighting in residential spaces with the exterior front barrier's heights.

Hence, it determines the optimal design of the windows under this effective factor in order to achieve appropriate levels of interior daylighting.

If windows are designed properly, they can contribute to achieving efficient levels of daylighting in the interior spaces.

\section{AIM OF THE RESEARCH}

This paper aims to study the effect of Window-Wall Ratio (WWR) in multi-story residential building as one of the passive design strategies to optimize daylighting in residential buildings in Mansoura City, according to the framework of the Egyptian Construction Law which puts a lot of parameters that affect the daylighting of buildings, including buildings height and its relationship to the street width in addition to linking windows area of the residential spaces toits area.

Thus to find a relationship between the percentage of housing openings and the elevation angle of the opposite 


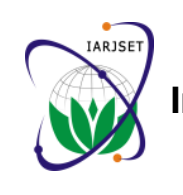

IARJSET

\section{International Advanced Research Journal in Science, Engineering and Technology \\ ISO 3297:2007 Certified \\ Vol. 4, Issue 3, March 2017}

buildings depending on the requirements of the global daylighting and compare that with the Egyptian Law.

\section{RESEARCH METHODOLOGY}

A. Simulation procedure:

The simulation software Rhino Program is used to design the case study and Diva Plugin in Rhino for parametric calculation of the daylight distribution.

\section{-Required input data for simulation software:}

The calculation parameters used by this program are shown in in Table I:

Table I: Utilized Radiance Simulation Parameters.

\begin{tabular}{|l|l|l|}
\hline Ambient bounces & 6 & 0 \\
\hline Ambient divisions & 1000 & 1000 \\
\hline Ambient sampling & 20 & 20 \\
\hline Ambient accuracy & .1 & .1 \\
\hline Ambient resolution & 300 & 300 \\
\hline
\end{tabular}

B. An Introduction to the Case Study:

\section{Location of the study:}

In order to re-study the optical behaviour to improve daylighting efficiency in Multi-Story Residential building in Egypt, the City of Mansoura (Taseem Khatab Residential Building Zone) was selected to be the research case study as shown in Fig.1, Fig2, Fig.3, and Fig.4.

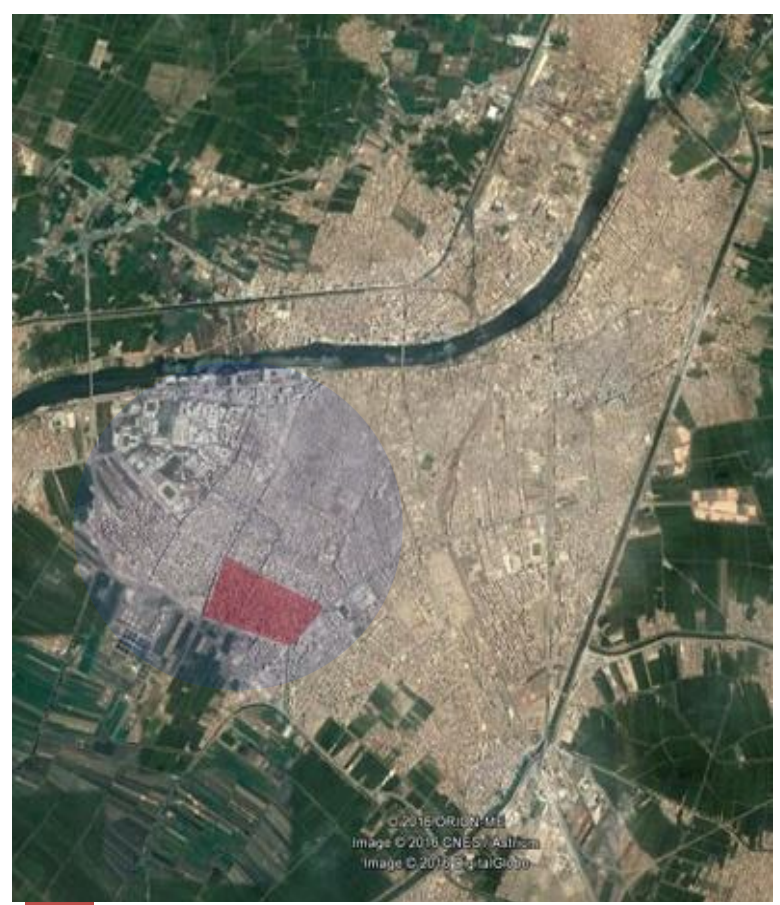

- Selected case study (tassem khatab residential buildings zone).

Fig.1.Satellite map of the location of Takseem Khatab residential buliding Zone from Mansoura City

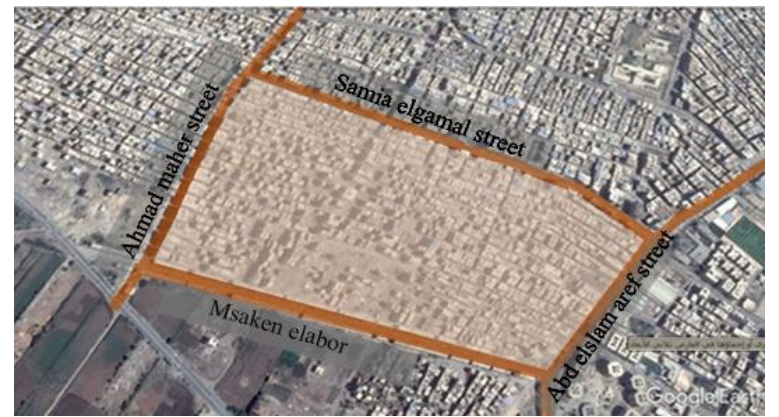

Fig. 2.Satellite map of Takseem Khatab residential building zone.

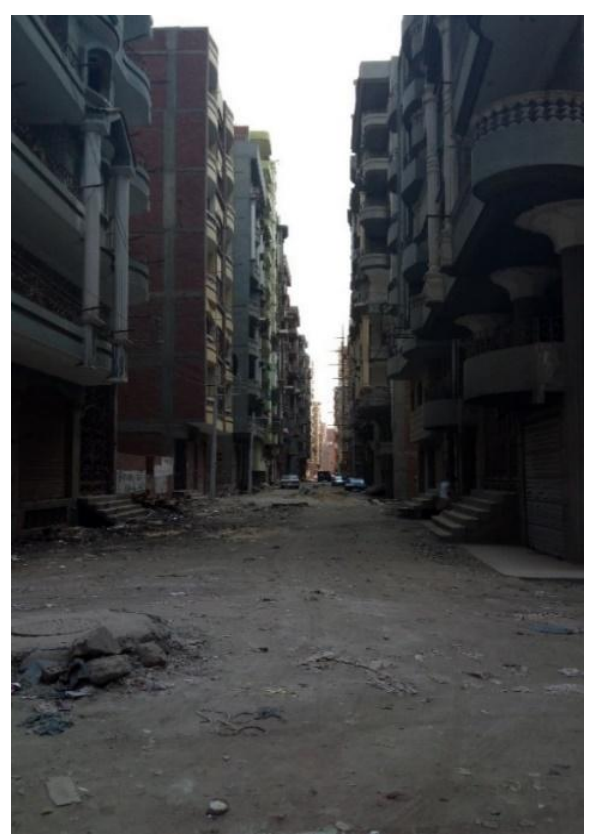

Fig .3. One of the streets in Takseem Khatab Zone.

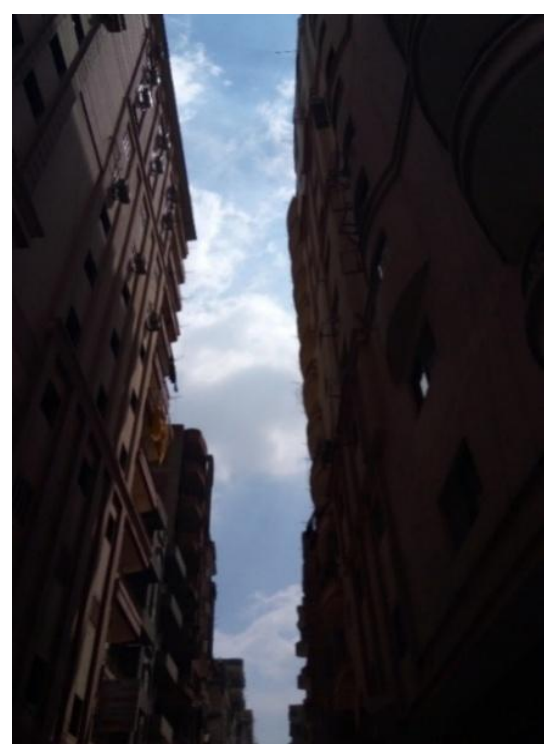

Fig. 4. Sample of residential building in selected Zone.

2. Case study zone:

Taseem khatab Indiscriminate Planning residential buliding zone: 


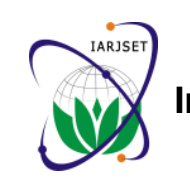

\section{IARJSET \\ Vol. 4, Issue 3, March 2017}

Eighty-five thousand citizens living in Taseem khatab in Mansoura City which includes 400 Building containing 15 thousand units. Many of the Buildings in this region were built before remove the Egyptian Law of Construction (119 for 2008) was active.

A mass residential area was built on the agricultural land of 45 feddans, this land was once enrolled as an agriculture land until 2006 when it was transform into a residential area.Fig. 5 shows the phases of urban sprawl of the residential building till now.

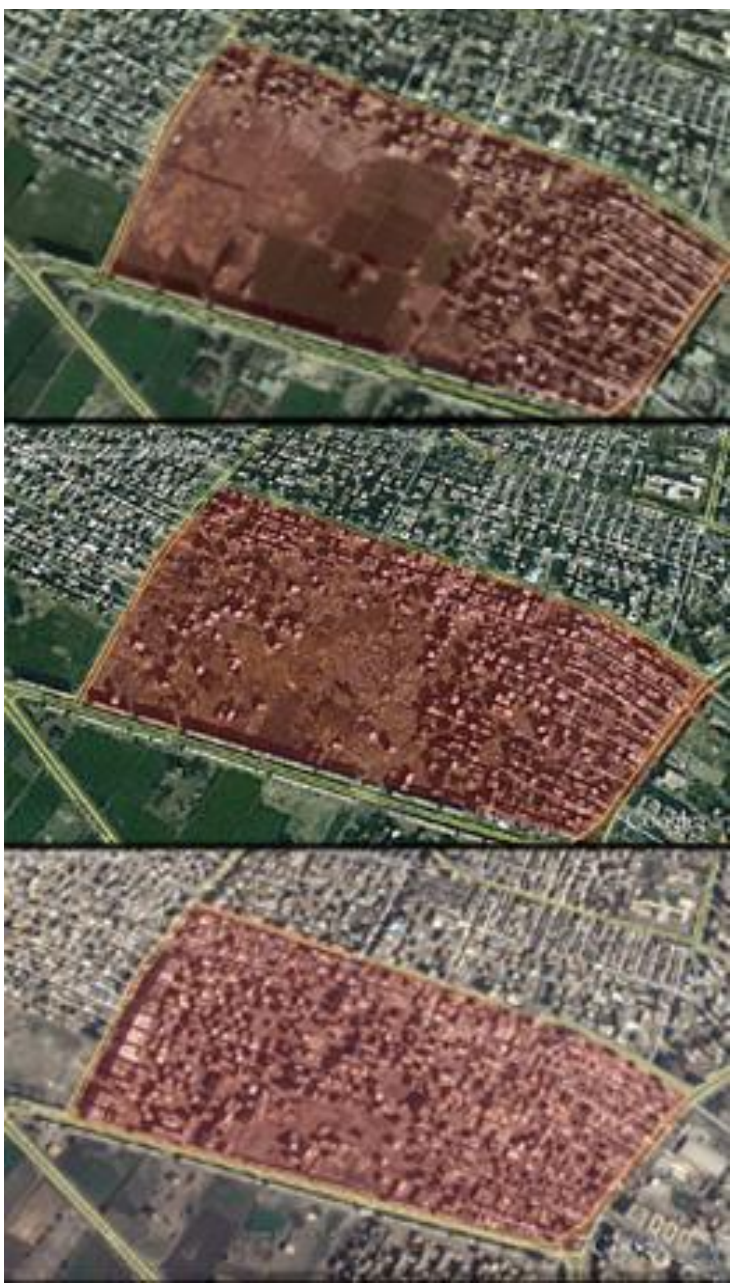

Fig.5.Phases of urban sprawl of residential buildings till now

-This residential units include residential buildings with a height ranges from 10 to 12 floor, and street width $8 \mathrm{~m}$, Figure 6.

- The construction Licence according to the Egyptian Construction Law for this Buliding (119 for 2008) had taken for a height of $\mathbf{1 . 5}$ street width which about $12 \mathrm{~m}$, equal to 4 stories.

- $\quad$ This means that all heights above the 5 storiesare considered illegal, causing dense urban areas with highrise buildings to occur.

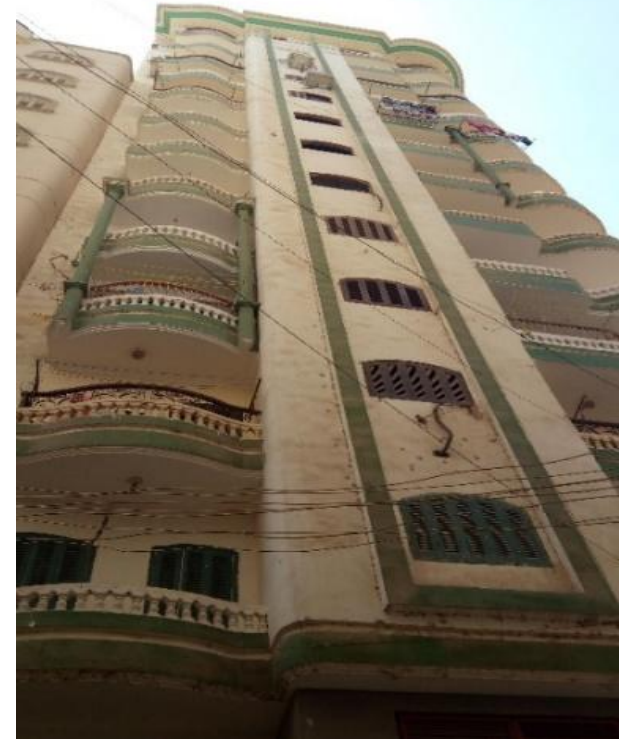

Fig. 6. Sample of residential buildings that illustrate building height.

C. Description of Methodology for Calculation:

1. Modelling of the case study residential space:

One Street is selected from the Takseem Khatab residential zone, fig.7. A residence built inside the street with a height of 12 stories to study the daylighting level inside. Fig. 8 illustrates the chosen residence built for the case study,fig.9. Illustrate Living room plan chosen for the case study.



Fig. 7.Selected Street for case study analysis from residential building zone 




Fig. 8. Chosen residence built for the case study.

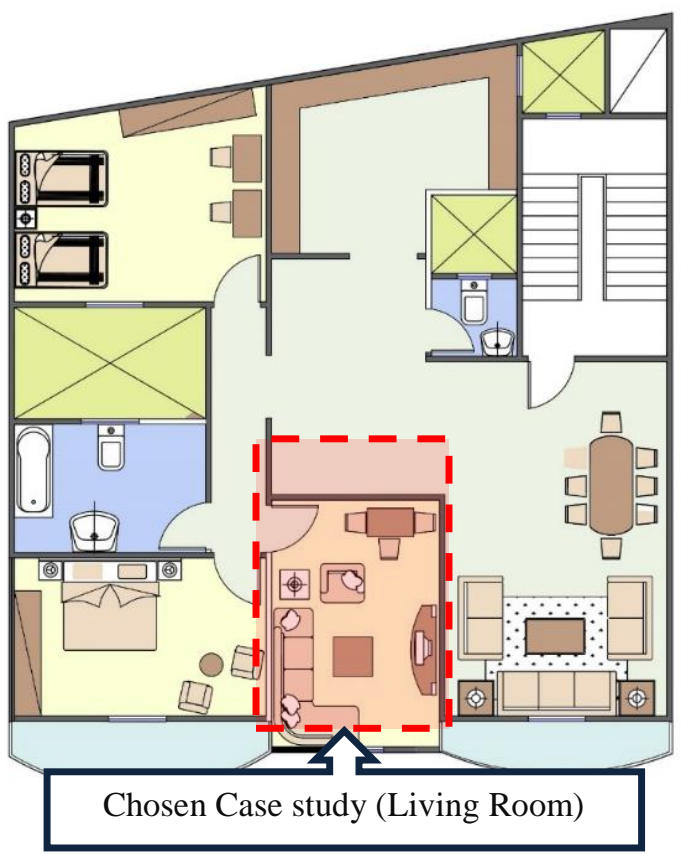

Fig. 9. Living room plan chosen for the case study

\section{Characteristics of Room Model:}

The selected Case study room with the dimensions of $3.6 \mathrm{~m}$ width, $5.4 \mathrm{~m}$ length, and $2.7 \mathrm{~m}$ internal height is shown in fig. 10 . The total area is $19.44 \mathrm{~m} 2$, with $52.45 \mathrm{~m} 3$ volume. The room walls have thickness of $0.12 \mathrm{~m}$, ceiling and floor had a thickness of $0.15 \mathrm{~m}$. The Window's area is variable, located in the 3.6wide façade, Configurations of selected case study model are show in Table II.

TABLE II: Configurations of selected case study model

\begin{tabular}{|l|l|}
\hline \multicolumn{2}{|c|}{ Living Room configurations } \\
\hline Dimensions & $3.6 \times 5.4 \times 2.7$ \\
\hline Area & $19.44 \mathrm{~m} 2$ \\
\hline Window orientation & South \\
\hline Occupancy schedules & $08: 00-18: 00$ \\
\hline
\end{tabular}

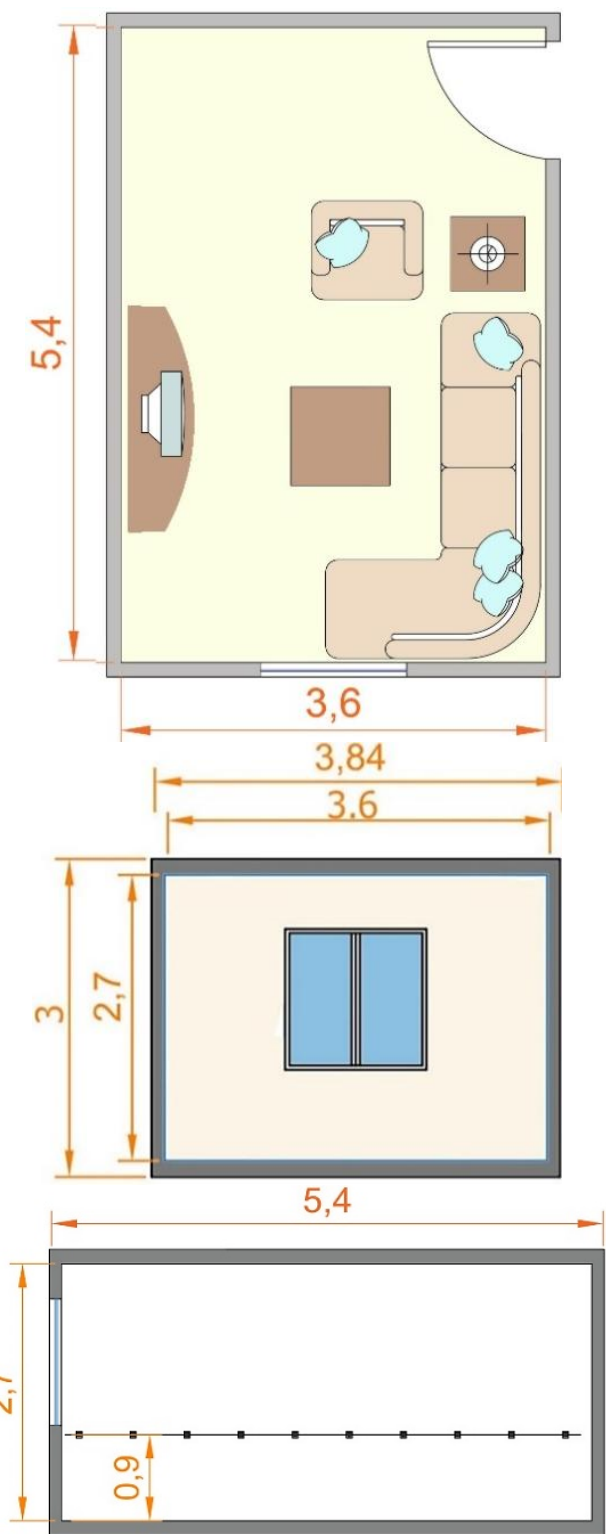

Fig.10.The selected case study Model Dimensions.

3. Materials used:

According to energy code of Energy Efficiency in Residential Building (EERB), the target illuminance for residential zone is 300 lux. Floor reflectance is $20 \%$, interior walls reflectance is $50 \%$, and celling reflectance is $80 \%$ and outer facades with reflectance $35 \%$ [1], Table III.

TABLE III: Properties of inner surfaces

\begin{tabular}{|l|l|}
\hline $\begin{array}{l}\text { Internal } \\
\text { Walls }\end{array}$ & $\begin{array}{l}\text { Material: 10mm White ivory plastic paint. } \\
\text { Reflectance:50\% }\end{array}$ \\
\hline Window & $\begin{array}{l}\text { Material: Single pane of glass with } \\
\text { aluminum frame. }\end{array}$ \\
\hline Floor & $\begin{array}{l}\text { Material :Wooden floor } \\
\text { Reflectance:20\% }\end{array}$ \\
\hline Celling & $\begin{array}{l}\text { Material: Bright white plastic paint. } \\
\text { Reflectance: } 80 \%\end{array}$ \\
\hline
\end{tabular}


D. Study Cases:

1. The study was divided into two consecutive phases.

These were as follows:

- First case study: WWR was tested for $16 \%$ which equal to $(8 \%$ of the room area) on the south façade facing the exterior barrier height from zero floor to 12 floors fig. 11. To examine which suitable angle of barrier height $(\theta)$ would reach of target illuminance level in case (WWR $=16 \%)$. Table IV illustrates the angle of barrier height $(\theta)$.

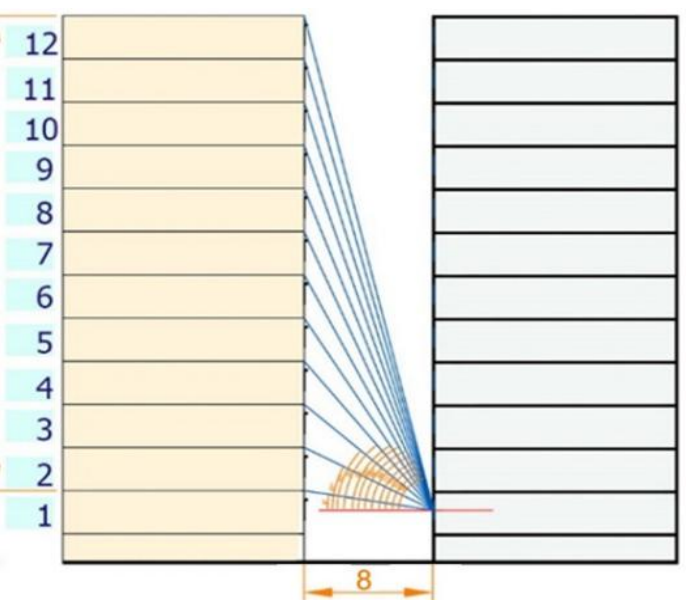

Fig.11.Street width is 8 meters as well as the building heights ranging from zero to 12 stories.

TABLE IV: The angle of barrier height $(\theta)$

\begin{tabular}{|l|l|}
\hline Floor number & Angel of barrier height $(\theta)$ \\
\hline 1 & $9^{\circ}$ \\
\hline 2 & $27^{\circ}$ \\
\hline 3 & $41^{\circ}$ \\
\hline 4 & $51^{\circ}$ \\
\hline 5 & $58^{\circ}$ \\
\hline 6 & $63^{\circ}$ \\
\hline 7 & $66^{\circ}$ \\
\hline 8 & $69^{\circ}$ \\
\hline 9 & $71^{\circ}$ \\
\hline 10 & $73^{\circ}$ \\
\hline 11 & $75^{\circ}$ \\
\hline 12 & $76^{\circ}$ \\
\hline
\end{tabular}

- Case Study two: WWR varies from $20 \%$ to $80 \%$ on the south façade. Table V shows the proposed WWR applied for the case studies.

TABLE V: The Proposed WWR and sizes



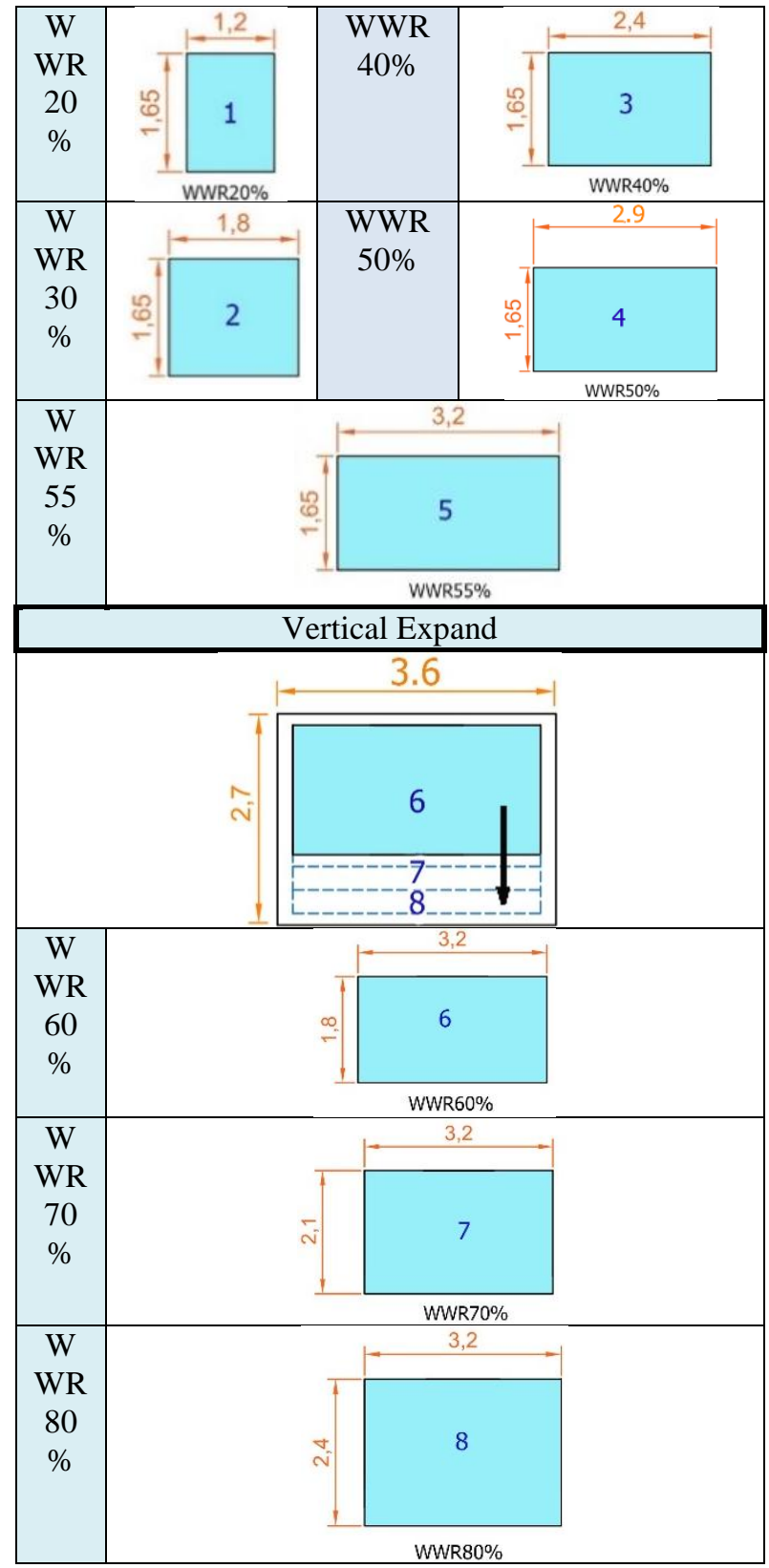

2. Variants and invariants:

Many factors affect daylighting level and assessment of energy consumption inside the residential buildings, Table VI.

TABLE VI: Variants and invariants factors.

\begin{tabular}{|l|l|l|}
\hline Parameters \\
\hline Geographic location & Fixed. & Mansoura City \\
\hline Area / volume & Fixed. & $\begin{array}{l}19.44 \mathrm{~m} 2 \\
/ 52.45 \mathrm{~m} 3\end{array}$ \\
\hline Function activity & Fixed. & Living Room \\
\hline orientation Sky & Fixed. & South \\
\hline $\begin{array}{l}\text { Vertical } \\
\text { Component (vsc):the } \\
\text { height of widow }\end{array}$ & $\begin{array}{l}\text { Window located } \\
\text { in Ground floor } \\
\text { plan. }\end{array}$ \\
\hline
\end{tabular}




\begin{tabular}{|l|l|l|}
\hline above the ground & & \\
\hline Street width & Fixed. & $8 \mathrm{~m}$ \\
\hline $\begin{array}{l}\text { Window design } \\
\text { position and ratio }\end{array}$ & Variant & $\begin{array}{l}\text { Window to wall } \\
\text { ratio varies from } \\
20 \% \text { to 80\% }\end{array}$ \\
\hline $\begin{array}{l}\text { Urban context , } \\
\begin{array}{l}\text { Height of opposite } \\
\text { building }\end{array}\end{array}$ & Variant & $\begin{array}{l}\text { Varies from 0 to } \\
12 \text { floor number. }\end{array}$ \\
\hline
\end{tabular}

\section{DETERMINANTS OF THE EGYPTIAN CONSTRUCTION LAW AND ITS IMPACT ON DAYLIGHTING [2]}

There are many determinants approved by the Egyptian unified code for construction (119 of 2008)which affectsdirectly on day lighting.

\section{A. Determinants Approved the Egyptian Unified Code} For Construction (119 of 2008) which Affects Directly on Daylighting:

1. Determinants of daylighting:

-The law stipulates that area of one opening or several openings of residential room used fordaylighting and ventilation and Overlooking the road or courtyard that must be at least $8 \%$ from total area of the residential room, and with a minimum area of $1 \mathrm{~m} 2$.

\section{Maximum heights of buildings:}

A maximum total height of the residential building equal one and half time (1.5) width of its opposite street, with a condition that this height doesn't exceed $36 \mathrm{~m}$.

\section{DAYLIGHT METRICS USED IN STUDY CASES}

- Daylight Autonomy (DA) is a dynamic metric used to measure the daylighting level in the residential spaces. The illuminance threshold for the DA metric in this research is 300 lux, this illuminance range compatible with the mean range of illuminance level in living room according to energy code of Energy Efficiency in Residential Building (EERB). The percentage of DA $\geq$ $50 \%$ is considered the threshold for a good daylighting level of residential living room [3].

- The DA metric used in this research is more recent, accurate and inclusive than currently used metrics in the Egyptian Standards. Thence the anticipated results from this application will meet or exceed the local standards.

\section{CLIMATE CONDITIONS OF MANSOURA CITY}

For analyzing Weather data and Climate conditions for the selected location (Mansoura City ) a Meteonorm Software programe is used. location for Mansoura City shows in TableVII and Sunshine duration for Mansoura city (by Meteonorm Software 7) shows in fig. 12.
The Meteonorm computer programme include Weather Data from location all over the world based on the latitude, the charactaristic of the location and other information that the user inputs, Meteonorm will generate asynthetic Weather file,these weather files are fairly accurate and sufficiently dependaple for the type of buliding energy analysis being discussed in this study[4].

TABLE VII: Meteonorm location for Mansoura city.

\begin{tabular}{|l|l|}
\hline City & Mansoura EG \\
\hline Latitude & $31.1^{\circ} \mathrm{N} / 31.4^{\circ} \mathrm{E}$ \\
\hline
\end{tabular}

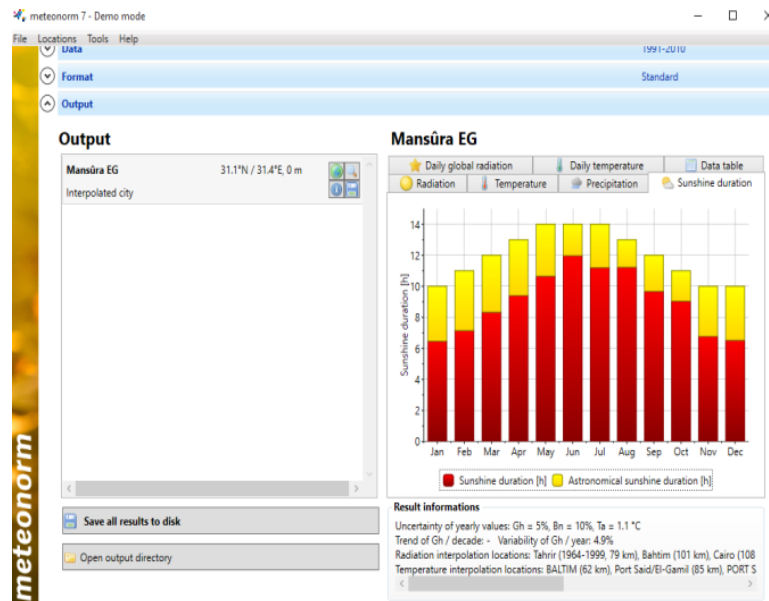

Fig.12. Sunshine duration for Mansoura City (by Meteonorm Software 7).

VII. CALCULATION:

Research consist of two study cases:

A. Case One:

Daylighting level for selected residential room settingin the Ground floor level, $(\mathrm{WWR}=16 \%)$ and opposite exterior Barrier's Heights variant from 0 to 12 stories: DA results show in fig.3. Maximam front barrier angle $\theta=20^{\circ}$ show in Table VIII.

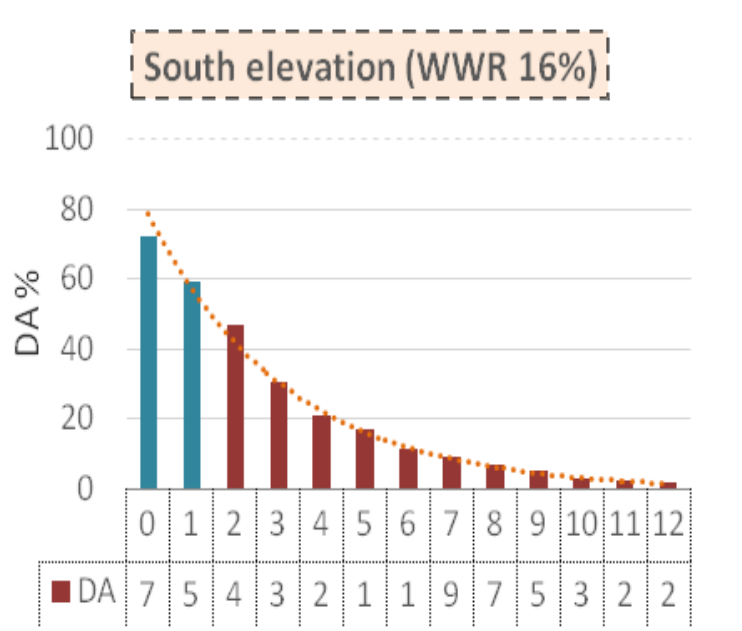

Fig. 13 . DA results $\mathrm{WWR}=16 \%$. 
TABLE VIII: Maximum front barrier angle $\theta=20^{\circ}$.

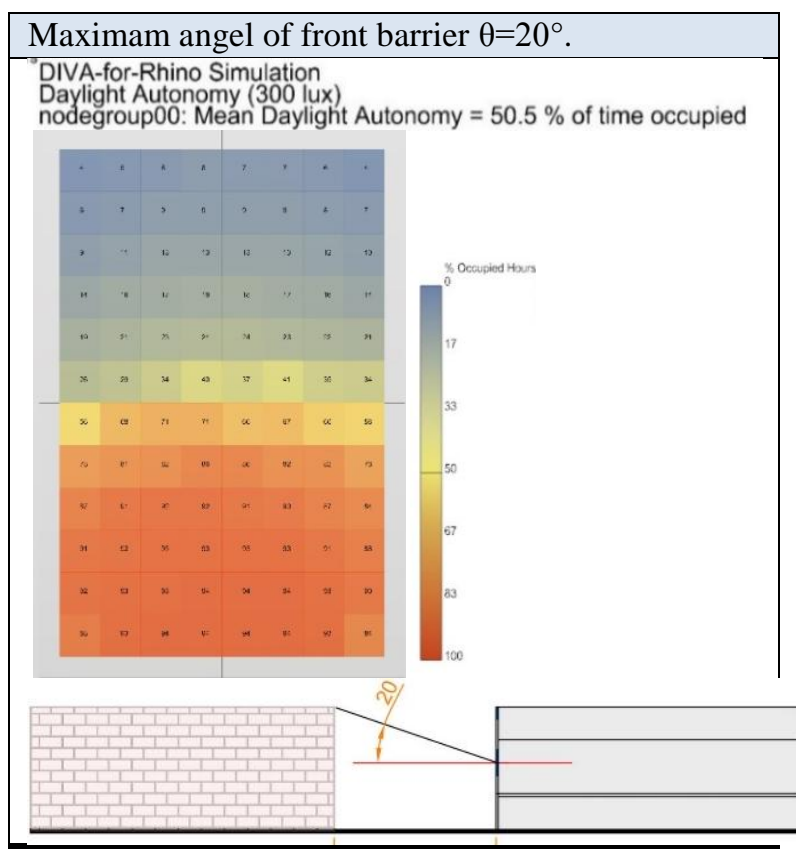

B. Case StudyTwo:

1. Assuming that $\mathrm{WWR}=20 \%$ :

DA results show in figure14, Maximam angel of front barrier $\theta=35^{\circ}$ show in Table IX.

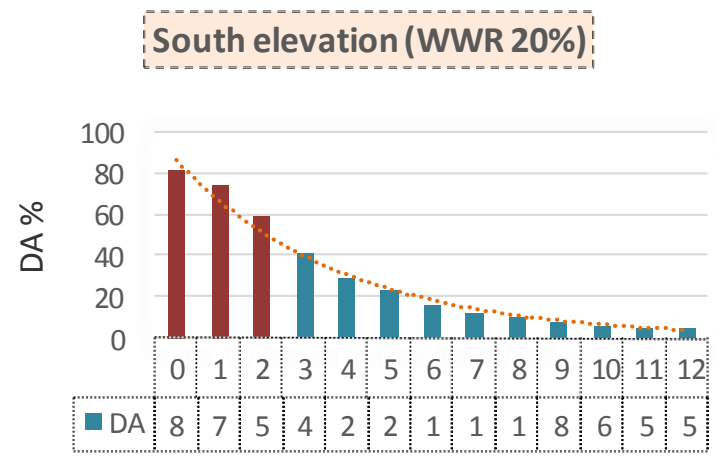

Fig.14. DA results $\mathrm{WWR}=20 \%$.

TABLE IX: Maximum angel of front barrier $\theta=35^{\circ}$.

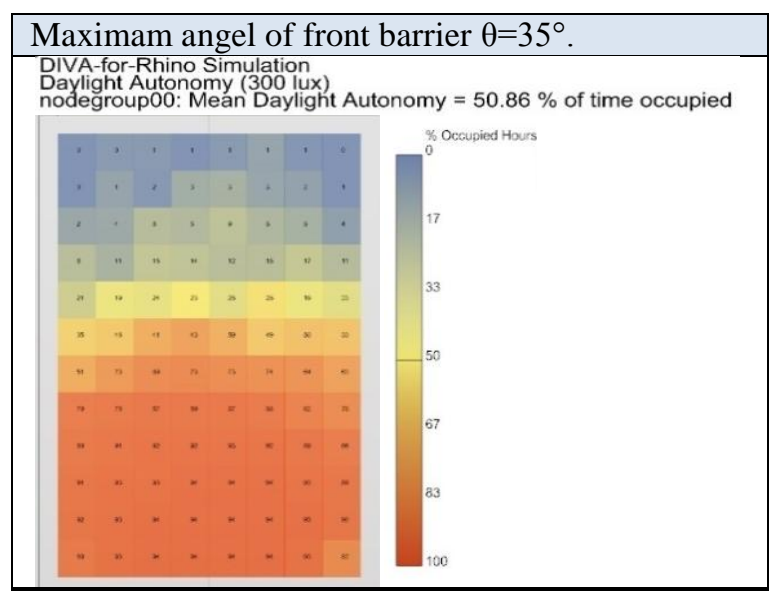

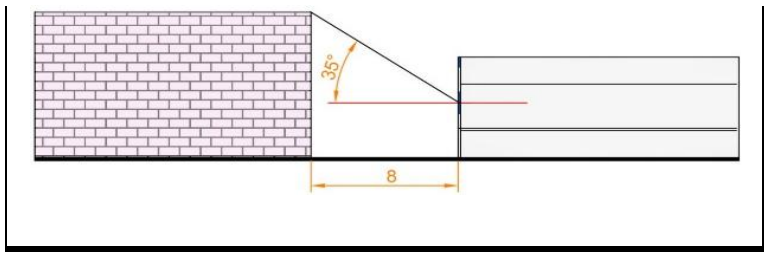

2. Assuming that WWR equal to $30 \%$ :

DA results show in fig. 15, Maximam front barrier angel $\theta=45^{\circ}$ shows in TableX.

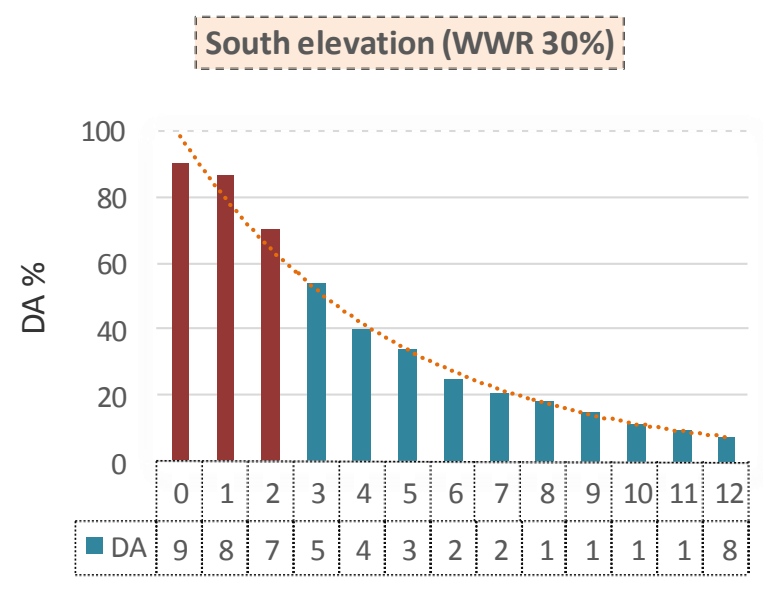

Fig.15. DA results WWR=30\%.

Table X: Maximum front barrier angel $\theta=45^{\circ}$.

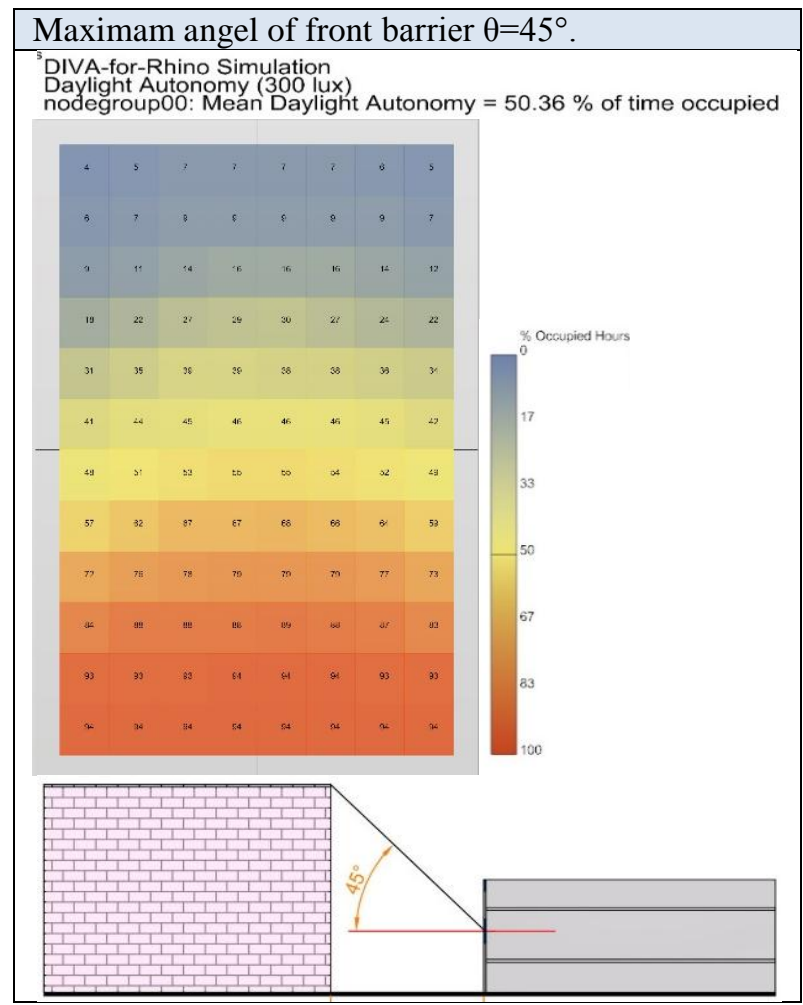

2. Assuming that WWR equal to $40 \%$ :

DA results show in fig.16, Maximum angel of front barrier $\theta=45^{\circ}$ shows in TableXI. 
International Advanced Research Journal in Science, Engineering and Technology

ISO 3297:2007 Certified

Vol. 4, Issue 3, March 2017

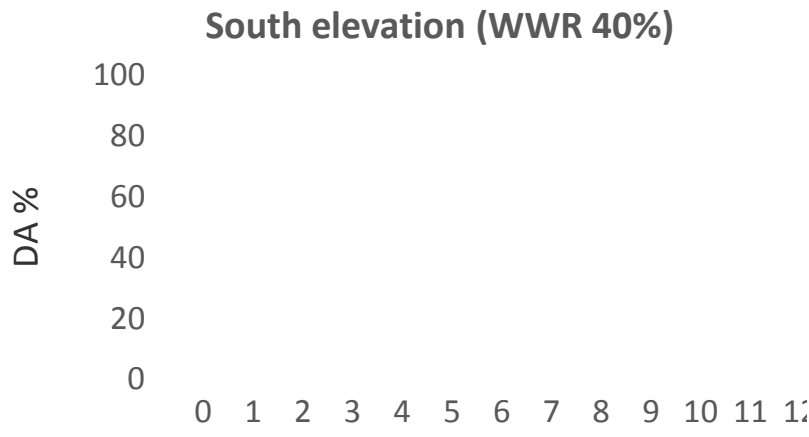

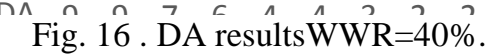

TABLEXI: Maximum angel of front barrier $\mathrm{s} \theta=49^{\circ}$.

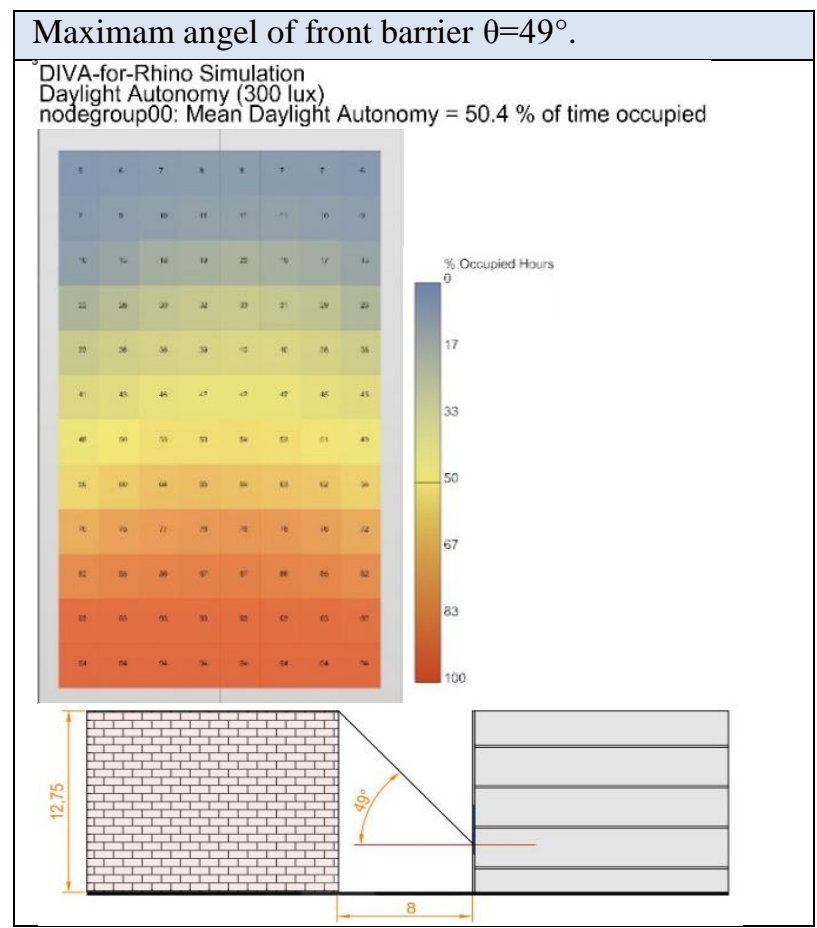

3. Assuming that WWR equal to 50\%:

DA results show in fig. 16, Maximumfront barrier angel $\theta=53^{\circ}$ shows in Table XII.

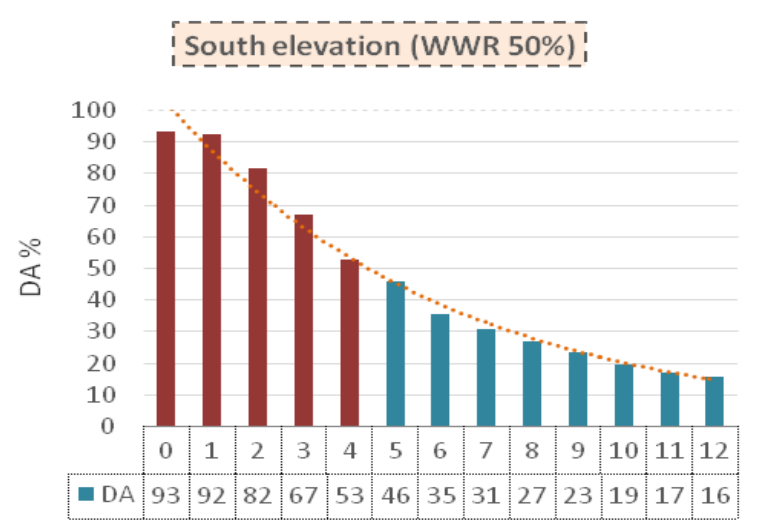

Fig. 16 . DA results WWR=50\%.
TABLEXII: Maximum angel of front barrier $\theta=53^{\circ}$.



5. Assuming that WWR equal to 55\%:

DA results show in figure 17, Maximum front barrier angel $\theta=53^{\circ}$ shows in Table XIII.

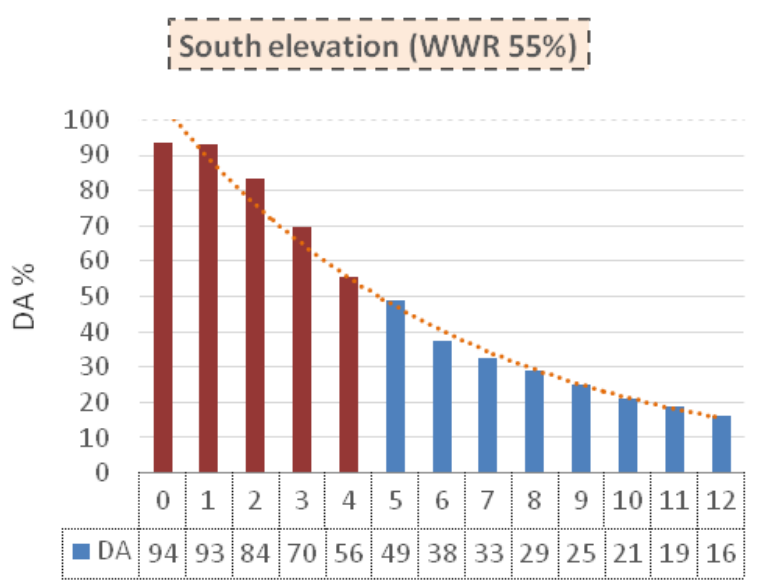

Fig. 17. DA results WWR $=55 \%$.

TABLE XIII: Maximum front barrier angel $\theta=56^{\circ}$.

\section{Maximam angel of front barrier $\theta=56^{\circ}$}

SDIVA-for-Rhino Simulation

Daylight Autonomy ( 300 lux $)$
nodegroup00: Mean Daylight Autonomy $=49.99 \%$ of time occupied 


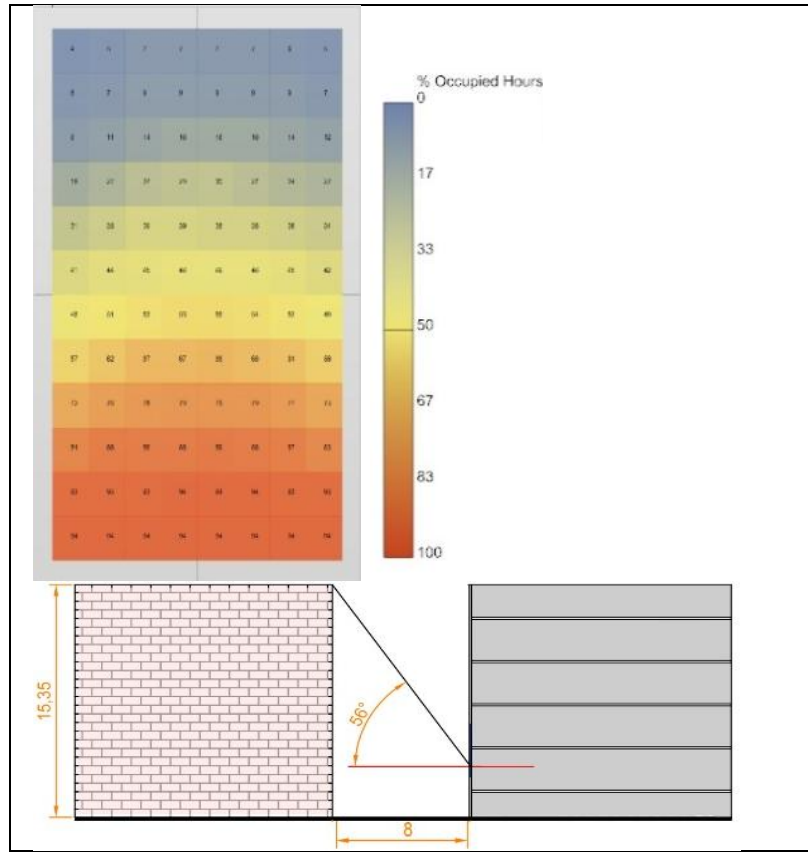

6. Assuming that WWR equal to $60 \%$ :

DA results show in fig.18, Maximam front barrier angel $\theta=58^{\circ}$ shows in Table XIV.



Fig.18. DA results WWR=60\%.

TABLE XIV: Maximum front barrier angel $\theta=58^{\circ}$





7. Assuming that WWR equal to70\%:

DA results show in fig.19, Maximum front barrier angel $\theta=59^{\circ}$ shows in Table XV.



Fig.19. DA results WWR=70\%.

TABLE XV: Maximum angel of front barrier $\theta=59^{\circ}$.

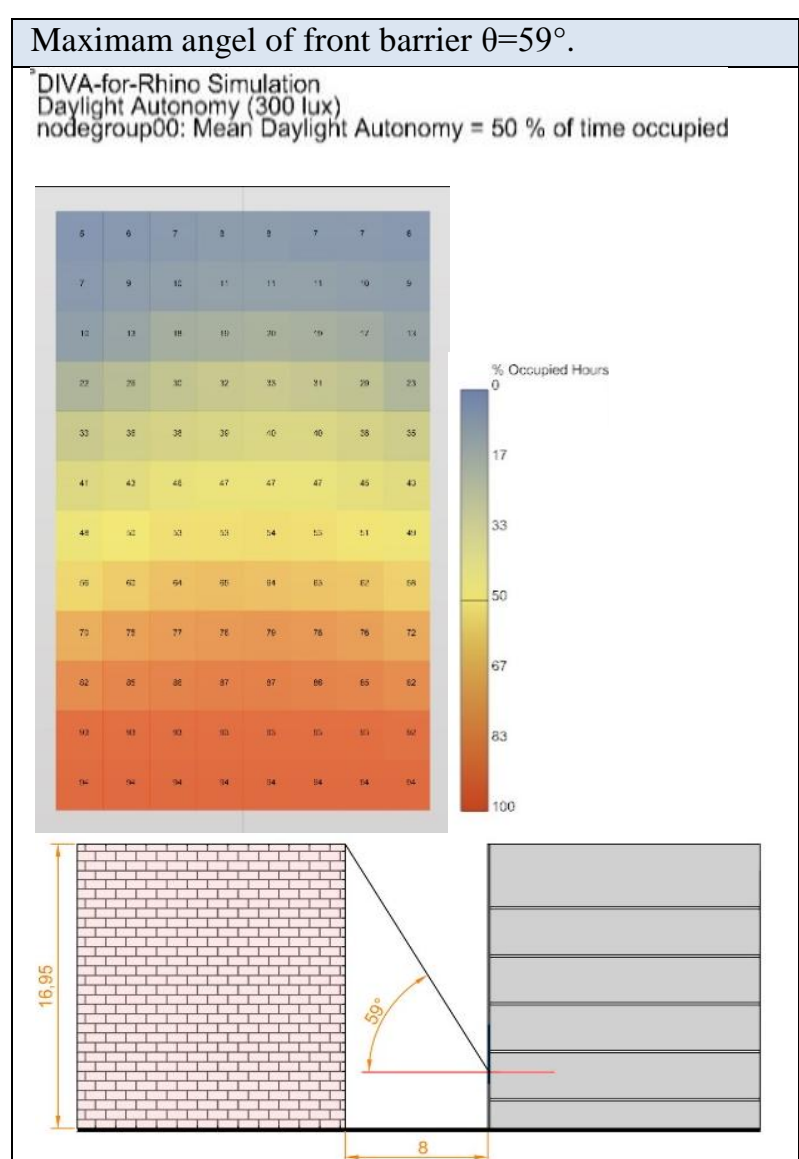


8. Assuming that WWR equal to $80 \%$ :

DA results show in fig.20, Maximum front barrier angel $\theta=60^{\circ}$ show in table XVI.



Fig.20 .daylight autonomy results $\mathrm{WWR}=80 \%$.

TABLE XVI: Maximum angel of front barrier $\theta=60^{\circ}$.



VIII. ANALYZING CALCULATION RESULTS:

A. WWR equal to $16 \%$ :

This result mean that, the percentage of window area $8 \%$ from its area, $\mathrm{WWR}=16 \%$ and street width $8 \mathrm{~m}$ suitable for building:
- Without any exterior barrier.

- Building with opposite exterior barrier with maximum barrier angel $\theta=20^{\circ}$.

B. WWR equal to $20 \%$ :

This result mean that, the percentage of window area $10 \%$ from its area, $\mathrm{WWR}=20 \%$ and street width $8 \mathrm{~m}$ suitable for building:

- Building with exterior front barrier angle from $\theta=20^{\circ}$ to maximum angel $\theta=35^{\circ}$.

C. WWR equal to $30 \%$ :

This result mean that, the percentage of window area $15 \%$ from its area, WWR $=30 \%$ and street width $8 \mathrm{~m}$ suitable for building:

- Building with exterior front barrier angle from $\theta=35^{\circ}$ to maximum angel $\theta=45^{\circ}$.

D. WWR equal to $40 \%$ :

This result mean that, the percentage of window area $20 \%$ from its area, $\mathrm{WWR}=40 \%$ and street width $8 \mathrm{~m}$ suitable for building:

- Building with exterior front barrier angle from $\theta=45^{\circ}$ to maximum angel $\theta=49^{\circ}$.

E. WWR equal to $50 \%$ :

This result mean that, the percentage of window area $25 \%$ from its area, WWR $=50 \%$ and street width $8 \mathrm{~m}$ suitable for building:

- Building with exterior front barrier angle from $\theta=49^{\circ}$ to maximum barrier angel $\theta=53^{\circ}$.

F. WWR equal to $55 \%$ :

This result mean that, the percentage of window area $27.5 \%$ from its area, WWR $50 \%$ and street width $8 \mathrm{~m}$ suitable for building:

- Building with exterior front barrier angle from $\theta=53^{\circ}$ to maximum angel $\theta=56^{\circ}$.

G. WWR equal to $60 \%$ :

This result mean that, the percentage of window area $30 \%$ from its area, WWR $=60$ and street width $8 \mathrm{~m}$ suitable for building:

- Building with exterior front barrier angle from $\theta=56^{\circ}$ to maximum angel $\theta=58^{\circ}$.

H. WWR equal to $70 \%$ :

This result mean that, the percentage of window area $35 \%$ from its area, $\mathrm{WWR}=70 \%$ and street width $8 \mathrm{~m}$ suitable for building:

- Building with exterior front barrier angle from $\theta=58^{\circ}$ to maximum barrier angel $\theta=59^{\circ}$.

I. WWR equal to $80 \%$ :

This results mean that, the percentage of window area $35 \%$ from its area, WWR $=80 \%$ (street width $8 \mathrm{~m}$ ) suitable for building:

- Building with exterior front barrier angle from $\theta=59^{\circ}$ to maximum barrier angel $\theta=60^{\circ}$. 
International Advanced Research Journal in Science, Engineering and Technology

\section{ISO 3297:2007 Certified}

Vol. 4, Issue 3, March 2017

\section{RESULTS} Daylight Autonomy calculation results: Table XVII: WWR or each floor:

Shows the accepted window size based on the opposing building height and fixed street wide $=8 \mathrm{~m}$, fig. 21 , Table XVII Illustrate the maximum angle of barriers height and

TABLEXVII: Shows the accepted window size based on the opposing building height and fixed street wide

\begin{tabular}{|l|l|l|l|l|l|l|l|l|l|l|l|l|l|}
\hline FLOOR & 0 & 1 & 2 & 3 & 4 & 5 & 6 & 7 & 8 & 9 & 10 & 11 & 12 \\
\hline$\theta$ & $0^{\circ}$ & $9^{\circ}$ & $27^{\circ}$ & $41^{\circ}$ & $51^{\circ}$ & $58^{\circ}$ & $63^{\circ}$ & $66^{\circ}$ & $69^{\circ}$ & $71^{\circ}$ & $73^{\circ}$ & $75^{\circ}$ & $76^{\circ}$ \\
\hline $16 \%$ & & & & & & & & & & & & & \\
\hline $20 \%$ & & & & & & & & & & & & & \\
\hline $30 \%$ & & & & & & & & & & & & & \\
\hline $40 \%$ & & & & & & & & & & & & & \\
\hline $50 \%$ & & & & & & & & & & & & & \\
\hline $55 \%$ & & & & & & & & & & & & & \\
\hline $60 \%$ & & & & & & & & & & & & & \\
\hline $70 \%$ & & & & & & & & & & & & & \\
\hline $80 \%$ & & & & & & & & & & & & & \\
\hline
\end{tabular}

DA>300lux exceed $50 \%$

DA>300lux not exceed $50 \%$

\section{- Result for south optimization:}

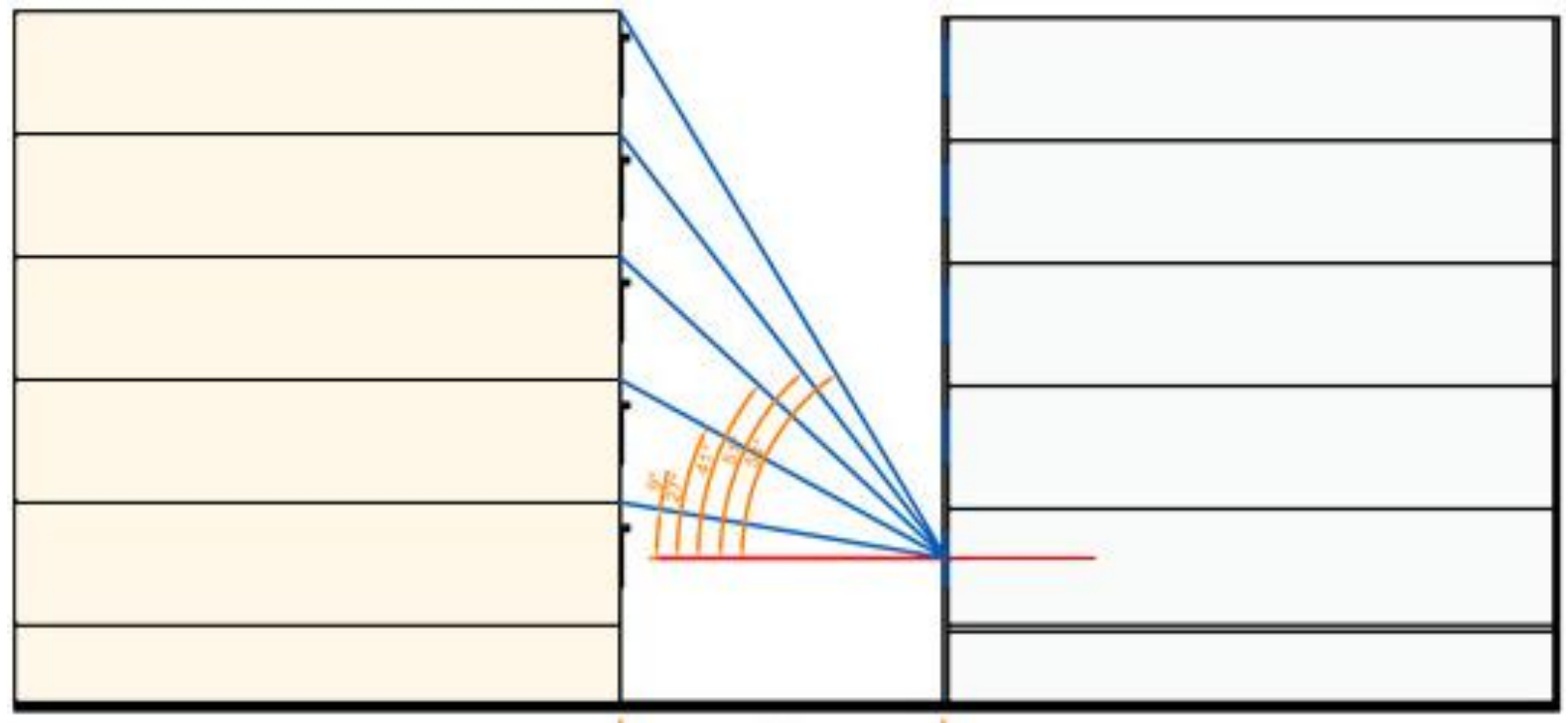

Fig.21: The Maximum Angle of barriers height. 
TABLE XVII: The maximum angle of barriers height and WWR or each floor.



A. In case that selected window area $8 \%$ from its area with opposite exterior building, the percentage of daylighting isn't achieved in all residential stories due to the incompatibility of required illumination intensity with the required global average of daylighting.

B. For selected case study, the Percentage of daylighting inside residential spaces achieved with window area and facing barrier $(\theta)$ according to the following:

1. In case of the Percentage of Window area $8 \%$ from its area (WWR16\%), maximum suitable angle of facing barrier $(\theta)$ is $\theta=20^{\circ}$.

2.

3. In selected case with street width $=8 \mathrm{~m}$, the maximum suitable height of opposite building equal five floor with WWR equal:

1- Ground floor WWR $=60 \%$.

2- First floor plan WWR $=50 \%$.

3- Second floor plan WWR $=30 \%$.

4- Third floor plan WWR $=20 \%$.

5- Fourth floor plan WWR $=16 \%$.

4. In selected case with street width $8 \mathrm{~m}$, the maximum suitable height of opposite building equal five floor. This mean that Total height of the residential Building $=2.1$ width from overlooking street. This percentage is different from the percentage approved by the Egyptian unified code for construction (119 of 2008) which equal one and half times (1.5) width of overlooking street.

\section{RECOMMENDATION}

A. Using the specialist computer software to analyze daylighting in residential buildings in the primary design stages of buildings, and the trade-offs between different design results.

B. We recommend doing a similar study to determine the percentage of window area and angle of barrier $(\theta)$ fronting him, according to various other uses, whether residential or administrative or commercial.

\section{REFERENCES}

[1] Energy planning center - natural and artificial lighting in buildings Architecture and Energyguide - July 1989.

[2] Ministry of Housing - Law 119 of 2008 in extending and organizing the construction work, 2009.

[3] Reinhart CF. Day lighting handbook I. Boston: Massachusetts Institute of Technology; 2014.

[4] Lerum, Vidar. High-performance building. John Wiley \& Sons, 2008 . 